\title{
ENVIRONMENTAL COSTS AND FINANCIAL PERFORMANCE OF OIL AND GAS COMPANIES IN NIGERIA
}

\author{
Oraka, Azubike 0. \\ Department of Accountancy \\ Nnamdi Azikiwe University, Awka \\ Mail: zubbike@gmail.com
}

\begin{abstract}
This study ascertains the effect of environmental costs on financial performance of oil and gas companies on the Nigeria stock exchange. The specific objectives are to: Ascertain the effect of Environmental Remediation Cost on Tobin's $Q$ of Oil and Gas Companies listed on Nigeria Stock Exchange, and evaluate the effect of Compliance Cost on Tobin's $Q$ of Oil and Gas Companies on the Nigeria Stock Exchange. Ex Post Facto research design was adopted for the study. Data were gathered from the published financial statements of the eleven (11) Oil and Gas companies for eleven (12) years period. The study found that Compliance Cost and Environmental Remediation Cost have significant effect on Tobin's $Q$ of Oil and Gas Companies listed on Nigeria Stock Exchange. Based on this, the researchers recommended amongst others that since Environmental Remediation Cost and financial performance are positively related, then oil and gas firms should be environmentally friendly to enable them gain competitive advantage, high liquidity and reduced environmental cost in the long run.
\end{abstract}

Keywords: Compliance Cost, Environmental Remediation Cost, and Tobin's Q 


\section{Introduction}

The creation of wealth has led to various environmental impacts such as depletion of nonrenewable resources, global warming, diminution of land resources, acidification, and reduction of water resources and potential threats to health and safety of employees (Singh, Murty, Gupta \& Dikshit, 2007). The issues of environmental abuses and degradation have led various sectors, governments and non-governmental organizations (NGOs) to engage in environmental sustainability debates and initiate strategies for responding to the challenges of sustainable development. Environmental costs include costs of complying with environmental laws. It includes environmental remediation costs, pollution control equipment costs and non-compliance penalty. Based on the meaning of environmental degradation, environmental cost could also cover the cost incurred to prevent degradation, cost of restating the environment to its original state, cost of restoring depleted environment to its normal position (Okafor, 2018). Profit ascertainment requires the subtraction of recurrent costs from revenues. Most often, the costs that leads to changes in the environment, which affect people adversely and cause damages to the environment are not taken into consideration before profits are determined. In other words, the profits could be wrongly determined. The result of this, in most cases, is reporting of wrong and excessive profits which will also mislead the decision makers.

The environment has a long history of being regarded as unrelated to the economic system (Solomon \& Darby, 2005). Businesses for many decades have ignored the impact of their activities on the natural and social environment in which they operated, unless it had direct repercussions on the profit and loss account. Friedman (1970) famously supported this classical view of business objectives by stating that the sole reason for a firm's existence is to maximize the wealth of the shareholders, and that any act of philanthropy equates to stealing from the shareholders' wealth. Failure of a business to meet this fiduciary obligation was not only reprehensible but would result in sanctions such as a drop in share price or an enforced change of management (Friedman, 1970). However, the neglect by business of the negative externalities arising from the pursuit of economic objectives along with various environmental abuses by companies (e.g. Royal Dutch/Shell Brent Spar dumping and Ogoni crises in 1995 and British Petrochemical Gulf of Mexico rig explosion in 2010) have created less than positive attitudes amongst stakeholders towards business. Rodriguez and Cruz (2007) argued that customers are gradually altering their purchasing attitudes towards behaviours that are more sensitive to the natural and social environment. This then risks a tarnished image for those firms not taking environmental issues seriously. The politico-legal system has also undergone drastic transformation, directed at limiting the environmental degradation caused by business activities. For example, many world leaders have made specific commitments towards a phased reduction in carbon dioxide emissions. The United States is committed to cutting emission by 17 per cent in 2020, 30 per cent by 2025, 42 per cent by 2030 and 83 per cent by 2050 . The United Kingdom is on course to meet its pledge to cut carbon dioxide levels by 34 per cent by 2020 and by 2050 to fulfill the target of an 80 per cent cut in greenhouse gases (Worthington, 2009). The United Nations conferences held in Copenhagen, Denmark in December 2009 and Durban, South Africa December 2011 are the most recent of the environmental summits reflecting this growing concern (Goldenberg, 2009; Jacob, 2011). 
Again businesses being partners in development and contributors to negative environmental impacts are expected to play lead role in instituting measures to mitigate their environmental impacts and achieve global reduction in negativities of their actions (Oliff and Vandermerve 2017) Peavler (2017) Gatimbu and Wabwire (2016) observed that businesses engaging in environmental management result in "win-win" situation and have better financial performance. Despite the observations some researchers such as Hossain, Islam and Andrew (2016) strongly kicked against spending on the environment stating that businesses' expenditure on the environment affect businesses bottom line.

In view of the inconclusiveness in study outcomes in this area and paucity of studies focusing on the oil and gas sector (arguably one of the worst culprits in environmental degradation), this study investigated the effect of corporate environmental cost on the profitability of oil and gas sector in Nigeria. More importantly, the focus of this study on the oil and gas sector filled a gap in knowledge on how environmental cost impact on the corporate profitability of the companies within the sector. This study ascertains the effect of environmental costs on financial performance of oil and gas companies on the Nigeria stock exchange. The specific objectives are to:

1. Ascertain the effect of Environmental Remediation Cost on Tobin's $Q$ of Oil and Gas Companies listed on Nigeria Stock Exchange.

2. Evaluate the effect of Compliance Cost on Tobin's $Q$ of Oil and Gas Companies listed on Nigeria Stock Exchange.

\section{REVIEW OF RELATED LITERATURE}

\subsection{Conceptual Review}

\subsubsection{Environmental Costs}

Environmental costs can be analyzed as relating to prevention, appraisal, internal failure and external failure activities (Eltaib, 2012). Prevention activities are activities that solve environmental problems before they occur or convert problems into opportunities. Cost of prevention activities are investment costs as they minimize future cost outlays and provide long-lasting benefits. Appraisal activities are activities that monitor the levels of environmental impact, for instance, auditing supplier performance, inspecting processes and products and measuring damage. Internal failure activities are activities that correct mishaps/ breakdowns noticed in appraisal activities. These costs include, cost of cleaning the plant after spillage, occupational health and safety claims of employees. External failure activities are activities which occur when resolution and remediation efforts fall outside the organization management. They include costs of cleaning polluted sites, fines and penalties for environmental damage and reduction of profits as a result of reputational injury. Environmental disclosure may result in long term sustainability of the firm as there is decreased wastage and improved efficiency hence resulting into low costs (Hossain, Islam \& Andrew, 2016).

Environmental costs are costs that the organization incurs to prevent, monitor and report environmental impacts (KPMG, 2012). United States of America Environmental Protection Agency (1995) defines five tiers of environmental costs namely; convectional, hidden, contingent, image and relationship and societal. These costs are broadly divided into two: 
private costs and societal costs. Private costs are borne by the firm whereas societal costs are borne by the society.

\section{Environmental Remediation Cost}

Environmental Remediation costs means all costs and expenses of actions or activities to cleaning up or removal of hazardous materials from the environment; preventing or minimizing the further movement, leaching or migration of hazardous materials in the environment; preventing, minimizing, or mitigating the release or threatened release of hazardous materials into the environment, or injury or damage from such release, and comply with the requirements of any environmental laws. Environmental remediation costs include, without limitation, costs and expenses payable in connection with the foregoing for legal, engineering or other consultant services, for investigation, testing, sampling, and monitoring, for boring, excavation, and construction, for removal, modification or replacement of equipment or facilities, for labor and material, and for proper storage, treatment, and disposal of hazardous materials (Burnett \& Hansen 2017). Remediation cost means all costs associated with performing work to remediate contamination of real property or groundwater, including engineering and other professional fees and expenses, costs to remove, transport and dispose of contaminated soil, costs to "cap" or otherwise contain contaminated soil, and costs to pump and treat water and monitor water quality (Bartolomeo, Bennett, Bouma, Heydkamp, James, \& Wolters, 2012).

\section{Compliance Cost}

Compliance cost refers to all the expenses that a firm incurs in order to adhere to industry regulations. Compliance costs include salaries of people working in compliance, time and money spent on reporting, new systems required to meet retention and so on. These costs typically increase as the regulation around an industry increases (Caputo, Veltri \& Venturelli, 2017). Compliance costs can be incurred as a result of local, national and international regulations, and they generally increase as a company operates in more jurisdictions. Global companies that have operations in jurisdictions all over the world with varying regulatory regimes naturally face much higher compliance costs than a company operating solely in one location (Will, 2018). Compliance cost is the total cost incurred by a firm to comply with applicable regulations. These regulations may cover such areas as tax reporting, environmental topics, transport, and finances. Compliance costs can include the following:

- Cost of the systems needed to collect information for compliance reporting.

- Cost of the personnel needed to construct and monitor the compliance systems.

- Cost to compile and issue reports.

Compliance costs can be so high in regulated industries that they represent a barrier to entry, which effectively creates an oligopoly. When this is the case, companies already competing in the industry may favor regulation in order to keep new entrants from appearing and increasing the level of competition. An organization operating in multiple jurisdictions may have to deal with a broader range of regulations, and so may incur higher costs than smaller competitors operating in fewer markets. This is a particular problem for organizations that 
operate internationally. Compliance costs are especially high for publicly held companies. These organizations have to maintain adequate control systems, while also producing a range of required reports for the Securities and Exchange Commission, These costs are so high that smaller organizations no longer find it cost effective to go public (Steven, 2019).

\section{Financial Performance}

Financial performance is measured to give the account of stewardship by the management team to the shareholders. The key aspect of this involves measuring the profitability, market value and growth prospect of a company. Accounting-based measures examines the nature of the relationship between some indicator of the social performance (reputation, revelation of social information, environmental behavior etc., with the company's financial performance obtained from the accounting information such as the historical audited financial statements of the respective companies (Zeng, Xu, Yin \& Tam, 2012).

\section{Tobin's Q}

The Tobin's Q ratio is a ratio devised by James Tobin of Yale University, Nobel laureate in economics, who hypothesized that the combined market value of all the companies on the stock market should be about equal to their replacement costs (Bond \& Cummins, 2004). Replacement value (or replacement cost) refers to the cost of replacing an existing asset based on its current market price. For example, the replacement value of a one-terabyte hard drive might be just N50 today, even if we paid N500 for the same storage space a few years ago (Amahalu, Okoye \& Obi, 2018). Tobin's q (also known as q ratio) is the ratio between a physical asset's market value and its replacement value (Hayes, 2019). The Q Ratio expresses the relationship between market valuation and intrinsic value. In other words, it is a means of estimating whether a given business or market is overvalued or undervalued (Hayes, 2019).

The $\mathrm{Q}$ ratio is calculated as the market value of a company divided by the replacement value of the firm's assets.

$\mathrm{Q}$ ratio $=\underline{\text { Total Market Value of firm }}$

Total Asset Value

For example, a low $\mathrm{Q}$ (between 0 and 1) means that the cost to replace a firm's assets is greater than the value of its stock. This implies that the stock is undervalued. Conversely, a high Q (greater than 1) implies that a firm's stock is more expensive than the replacement cost of its assets, which implies that the stock is overvalued. This measure of stock valuation is the driving factor behind investment decisions in Tobin's model (Maverick, 2018). The formula for Tobin's Q ratio takes the total market value of the firm and divides it by the total asset value of the firm. For example, assume that a company has $\$ 35$ million in assets. It also has 10 million shares outstanding that are trading for 4 a share. In this example, the Tobin's $\mathrm{Q}$ ratio would be:

Tobin's $\mathrm{Q}$ ratio $=$ total market value of firm / total asset value of firm $=\$ 40,000,000$ / $\mathrm{N} 3,000,000=1.14$

\section{Empirical Studies}


Bessong and Tapang (2012) determined the influence of social responsibility cost on the profitability of Nigerian banks. The study made used of an exploratory research design and data were collected from five Nigerian banks through secondary sources and analyzed using the Ordinary Least Square (OLS) method. The study revealed that there is a negative influence between social cost and pollution cost on profitability. Conclusively, social responsibility cost is as vital as all other liabilities of the banks, and it requires proper management. It was recommended that the Financial Reporting Council (FRC) of Nigeria should collaborate with other professional bodies, the academia and other stakeholders to produce a standard on social responsibility accounting and should ensure there is compliance and transparency in the process. Swinkels (2012) examined the relation between the disclosure of a GRI sustainability report by companies and financial performance. A study by KPMG (2005) among the top 250 firms from the Global Fortune 500 indicated that $74 \%$ of the companies that publish these reports do it for economic reasons. Therefore the study focused on firms that publish these reports to see if this is the case and it is financial performance that motivates companies to publish sustainability reports. The results of this study suggested there is no relation between the publication of a GRI sustainability report and financial performance in general. Also the study offered no evidence of a relation between a firm's application level of the GRI framework and guidelines and financial performance. Okoye, Oraka and Ezejiofor (2013) examined whether on social sustainability reporting has effected any changes on internal and external perceptions of corporate organization and to determine the extent at which pressure from external factors has contributed in the needed social sustainability reporting in Nigeria. Survey research method was adopted and questionnaire was administered on a random selected sample of eighty (80) employees, customers and investors in manufacturing organizations in Onitsha, Anambra state. Using five point likert scale for analysis and z-test statistical tool to test the two hypotheses, the study found out that Social sustainability reporting has effect on the changes of internal and external perceptions of corporate organization and that Pressures from external factors have contributed to social sustainability reporting of corporate organization. Makori and Jagongo (2013) ascertained whether there is any significant relationship between environmental accounting and profitability of selected firms listed in India. The data were analyzed using multiple regression models. The key findings of the study shows that there is significant negative relationship between Environmental Accounting and Return on Capital Employed (ROCE) and Earnings per Share (EPS) and a significant positive relationship between Environmental Accounting and Net Profit Margin and Dividend per Share. Tze, Boon and Yee (2014) analyzed the relationship between environmental improvement and the financial performance of firms on a sample of 78 leading companies listed in Bursa Malaysia. The study covered a period of 5 years, from 2008 to 2012. The study used content analysis to verify the extent of information disclosed and reported by companies. The results indicated there is a positive correlation between efficiency used towards natural resources and financial performance (both ROA and ROE). On the other hand, (Materials, Energy and Water were found to be negative predictor for ROA and ROE. Okoye and Ezejiofor (2013) determined the appraisal of Sustainability environmental accounting in enhancing corporate performance and economic growth. This study reviewed various forms including journal papers, articles and other relevant materials. This paper analyzed and tested two hypotheses with Pearson Product Movement Correlation Co-efficient. Based on this, the study discovered that sustainable environmental accounting has significant impact on corporate productivity in order to enhance corporate growth. Bai, Pingli and Zhuang (2014) investigated the effect of multi-dimensional corporate environmental performance (CEP) on firm's financial performance and risk in Pakistan from 
2005-2012. Considering two dimensions of CEP as environmental management performance (EMP) and environmental operational performance (EOP), the study found an inverted Ushaped relationship between carbon performance and Tobin's Q, and a positive relationship between EMP and Tobin's Q. The findings also provided evidences for the moderation effect of EMP on the EOP-Tobin's Q relationship. Delmas, Nairn-Birch and Lim (2015) determined the dynamics of environmental and financial performance: The case of greenhouse gas emissions (GGE). The study found that during this period, improving corporate environmental performance causes a decline in an indicator of short-term financial performance, return on assets. Nonetheless, investors see the potential long-term value of improved environmental performance, manifested by an increase in Tobin's q. Dobre, Stanila and Brad (2015) provided information on how Romanian listed companies report environmental and social indicators and whether or not this has an impact on financial performance. The study used a four time period panel fixed effect model for Romanian companies that are listed in the first category of the Bucharest Stock of Exchange from 20102013. The results pointed out that increasing water, air and soil protection has a negative impact on current return on equity, while no effects were detected on return on assets and stock market returns. Rokhmawati, Sathye and Sathye (2015) aimed to understand the effect of GHG emissions, environmental performance (EP), and social performance (SP) on financial performance (FP) of listed manufacturing firms in Indonesia. Sampling was based on the availability of the firms' annual reports 2011 and interview feedback about the type and amount of fossil fuels and electricity consumed by the firms in 2011. The study found that $\mathrm{CO} 2 \mathrm{e}$ intensity and social reporting scores have a positive and significant effect on ROA. The coefficient of proper rating was not significant. Ezejiofor, John-Akamelu and Chigbo (2016) assessed the effect of sustainability accounting measure on the performance of corporate organizations in Nigeria from 2010-2015. Ex post facto research design and time series data were adopted. Data for study was collected from annual reports and accounts of the company in Nigeria. Formulated hypotheses were tested using Regression Analysis with aid of SPSS Version 20.0. Based on the analysis, the study found that environmental cost does not impact positively on revenue of corporate organizations in Nigeria, also that environmental cost impact positively on profit generation of corporate organizations in Nigeria. Bartolacci, Paolini, Soverchia and Zigiotti (2016) analyzed the profitability of listed companies in Italy from 2009 to 2014. The empirical analysis using ordinary least square regression analysis was carried out on a population of 298 Italian companies.. However, combining this information with that concerning separate waste collection, a clear relationship - both positive and negative - is not identifiable. Elias, Kostas and Dimitris (2016) examined the causal linkage between environmental and financial performance in Greek manufacturing firms from 2004-2014. Empirical findings suggested that there seems to be a link between these dimensions irrespectively of the particular sector of activity. Contrary to similar studies a "virtuous circle" does not exist as the avoidance of environmental improving investments is related to a better financial performance. Pariag-Maraye, Ansaram and Ramkalawon (2017) examined the relationship between environmental management practices adopted by listed firms on the Stock exchange of Mauritius and their impact, if any, on their financial performance. A content analysis of annual reports of the listed companies over the period 2011 to 2014 to determine the level of environmental management systems (EMS) was implemented by the local firms. For the purpose of the research, the environmental management practices were classified into 6 categories namely pollution control, waste reduction, recycling, cutting use of energy, cutting paper consumption and carbon footprint reduction based on extant literature. The study revealed that there is an 
insignificant relationship between environmental management practices and financial performance except for cutting use of energy which generated a significant relationship. The results found that companies tend to be more environmentally conscious due to compliance rather than a voluntary basis or to reap corporate benefits. Worae and Ngwakwe (2017) examined environmental responsibility and financial performance nexus of Johannesburg Stock Exchange's socially responsible investing manufacturing and mining firms during the period of 2008-2014. The study employed annual panel dataset of fourteen manufacturing and mining companies on the index, and Granger causality analysis using Gcause2 Baum's version. The study found unidirectional causal relationship between environmental responsibility, measured by emissions intensity and equity returns, and bidirectional causal relationship between emissions intensity and market value of equity deflated by sales at $1 \%$ significant levels. Impliedly, improvements in 'energy efficient technologies' to reduce fossil-energy consumption (prevention activities) seem to exhibit value destroying tendencies, while improvements in 'end-of-pipe' activities seem to estimate a drive market value of equity deflated by sales and equity returns. Azomahou, Van \& Wagner (2017) examined the relationship between the environmental and economic performance of firms in the European paper manufacturing industry from 2011-2015. Based on panel data, it investigated the relationship separately, with the analysis based on four hypotheses formulated with regard to country influence, process influence and firm size influence on environmental and economic performance. Udeh and Ezejiofor (2018) determined the effect of sustainability cost accounting on financial performance of Nigerian telecommunication firms. Ex post fact research design and time series data were adopted. Formulated hypotheses were tested using regression analysis with the aid of SPSS Version 20.0. Based on this, the study found that Sustainability cost accounting has significantly affected return on assets of Nigerian telecommunication firms. Another finding is that sustainability cost accounting has significantly affected return on equity of Nigerian telecommunication firms. Okafor (2018) ascertained the effect of environmental costs on firm performance. To achieve this objective, the study made use of financial reports of Oil and Gas Companies quoted in the Nigerian Stock Exchange Market from years 2006-2015. Regression analysis was employed with the aid of Statistical Package for Social Sciences (SPSS). The results of the statistical analysis indicated that better environmental performance positively impact business value of an organization. Moreover, environmental accounting provides the organization an opportunity to reduce environmental and social costs and improve their performance. Nyirenda, Ngwakwe and Ambe (2018) examined the impact of environmental management practices on the financial performance of a South African mining firm. The approach is a case study of a South African mining firm listed under the socially responsible index (SRI) of the Johannesburg Stock Exchange (JSE) from 2009-2016. The result showed there is no significant relationship between the variables and this lends credence to information gathered from Green-Steel environmental reports that Green-Steel's environmental management practices are driven mostly by a desire to abide by regulations and also by a moral obligation to use environmental management practices to mitigate climate change impact. Falope, Offor and Ofurum (2019) ascertained the effect of Environmental Disclosure and Performance of Quoted Nigerian Construction Firms. Hypotheses were tested using linear regression analysis with the aid of SPSS Version 20.0. It was observed that environmental pollution prevention cost, environmental protection cost and environmental recycling disclosure have effects on return on assets of quoted construction firms in Nigeria. Iheduru and Chukwuma (2019) examined the effect of environmental and social costs on performance of manufacturing companies in Nigeria. The objectives of this study are to examine the relationship between 
environmental and social costs and performance of manufacturing companies in Nigeria. The data were analyzed using multiple regression models. The key findings of the study shows that there is significant negative relationship between Environmental and social costs and Return on Capital Employed (ROCE) and Earnings per share (EPS) and a significant positive relationship between environmental and social costs and Net Profit Margin (NPM) and Dividend per Share (DPS).

In view of the inconclusiveness in study outcomes in this area and paucity of studies focusing on the oil and gas sector (arguably one of the worst culprits in environmental degradation), this study investigated the effect of corporate environmental cost on the profitability of oil and gas sector in Nigeria. More importantly, the focus of this study on the oil and gas sector filled a gap in knowledge on how environmental cost impact on the corporate profitability of the companies within the sector.

\section{Methodology}

\section{Research Design}

The research design employed in this study is the ex-post facto research design, in order to establish a relationship between environmental cost and financial performance. This study was treated as ex-post facto research since it relied on historical data. This is appropriate because ex-post facto research aims at measuring and establishing the relationship between one variable and another or the effect of one variable on another, in which the variables involved are not manipulated by the researcher (Kothari \& Garg, 2014).

Eleven (11) Oil and Gas companies were selected as the sample size of this study with the utilization of purposive sampling method. Data were gathered from the published financial statements of the eleven (11) Oil and Gas companies for eleven (12) years period spanning from 2008-2019, using Purposive sampling method (that is all the Oil and Gas firms that filed their annual financial statements with NSE from 2008-2019. The reason for the choice of this time frame is availability of published annual report and accounts of the selected organizations and to have a fairly, reasonably, reliably and up-to-date available financial data.

Both the dependent and independent variables were computed from the data extracted from publications of the Nigerian Stock Exchange (NSE), the annual report and accounts of the sampled listed Oil and Gas companies and ratios were computed from the figures as reported in the annual reports.

\section{Method of Data Analysis}

The data analysis for the study took the form of descriptive statistics and inferential statistics. This research work adopted the panel least square (PLS) regression analysis with longitudinal (panel) regression using E-Views 9.0 statistical software. The reason for adopting panel data regression is because of the number of Oil and Gas firms and the period of time involved (Koutsoyiannis, 2001). 


\section{Independent Variables}

The independent variable in this study is environmental cost which was proxied with:

Employee Health and Safety Cost, Waste Management Cost and Community Development Cost, Environmental Remediation Cost and Compliance Cost.

i) Environmental Remediation Cost (ERC): Obtained from the annual reports and accounts of the respective sampled companies for the study period (various issues).

ii) Compliance Cost: Obtained from the annual reports and accounts of the respective sampled companies for the study period (various issues).

\section{Dependent Variables}

The dependent variable which is financial performance was measured by:

i. Tobin's Q: A ratio of a company's market value to its total asset value. The $\mathrm{Q}$ ratio is calculated as the market value of a company divided by the replacement value of the firm's assets.

$$
\text { Tobin's Q }=\frac{\text { Total Market Value of Firm }}{\text { Total Asset Value }}
$$

\section{Control Variables}

In conducting the linear multiple regression analysis, the following control variables were included:

(a) Size of the firm (FSZ): Size of the firm as measured by the natural log of total assets, is used to control the impact of size on wealth creation.

(b) Leverage (LEV):

Financial leverage as measured by total debt divided by total equity is used to control the impact of debt servicing on corporate performance and wealth creation

$$
\text { LEV }=\frac{\text { Total debt }}{\text { Total equity }}
$$

\section{Model Specification}

The following research models were formulated in line with the research hypotheses in order to empirically determine the effect of environmental cost on financial performance.

$$
\begin{array}{lllllll}
\mathrm{TQ}_{\mathrm{it}}= & \beta_{0}+\beta_{1} \mathrm{ERC}_{\mathrm{it}}+\beta_{2} \mathrm{FSZ}_{\mathrm{it}}+\beta_{3} \mathrm{LEV}_{\mathrm{it}}+\mu_{\mathrm{it}} & - & - & - & - & \mathrm{i} \\
\mathrm{TQ} & = & \beta_{0}+\beta_{1} \mathrm{CC}_{\mathrm{it}}+\beta_{2} \mathrm{FSZ}_{\mathrm{it}}+\beta_{3} \mathrm{LEV}_{\mathrm{it}}+\mu_{\mathrm{it}} & - & - & - & -
\end{array}
$$

Where:

$\mathrm{TQ}_{\mathrm{it}}=$ Tobin's $\mathrm{Q}$ of firm $i$ in period $t$ 
$\mathrm{ERC}_{\mathrm{it}}=$ Environmental Remediation Cost of firm $i$ in period $t$

$\mathrm{CC}_{\mathrm{it}}=$ Compliance Cost of firm $i$ in period $t$

$\mathrm{FSZ}_{\mathrm{it}}=$ Firm Size of firm $i$ in period $t$

$\mathrm{LEV}_{\mathrm{it}}=$ Leverage of firm $i$ in period $t$

$\mu_{i, t}=$ component of unobserved error term of firm $i$ in period $t$

$\beta_{0}=$ constant term

$\beta_{1}, \beta_{2}$ and $\beta_{3}=$ are slopes to be estimated of firm $i$ in period $t$.

$\mathfrak{i}=$ firm identifier (11 firms)

$\mathrm{t}=$ time variable $(2008,2009, \ldots \ldots .2019)-($ Twelve Years $)$

\section{Decision Rule:}

Accept $\mathrm{H}_{0}$, if the P-value of the test is greater than 0.05 , otherwise reject.

\section{Data Presentation and Analysis}

\section{Data Analysis}

\section{Table 1: Descriptive Statistics}

$\begin{array}{lcrrrr} & \text { TQ } & \text { ERC } & \text { CC } & \text { FSZ } & \text { LEV } \\ \text { Mean } & 0.359167 & 0.684167 & 0.115000 & 11.08667 & 9.278333 \\ \text { Median } & 0.220000 & 0.735000 & 0.110000 & 11.03500 & 8.965000 \\ \text { Maximum } & 1.230000 & 0.910000 & 0.150000 & 12.57000 & 11.06000 \\ \text { Minimum } & 0.030000 & 0.370000 & 0.100000 & 9.930000 & 7.250000 \\ \text { Std. Dev. } & 0.330494 & 0.180225 & 0.015076 & 0.885698 & 1.110150 \\ \text { Skewness } & 1.698272 & -0.631193 & 1.080800 & 0.104796 & -0.071313 \\ \text { Kurtosis } & 5.087121 & 2.252931 & 3.374400 & 1.742367 & 2.146244 \\ \text { Jarque-Bera } & 7.946290 & 1.075865 & 2.406344 & 0.812785 & 0.374620 \\ \text { Probability } & 0.018814 & 0.583954 & 0.300240 & 0.666049 & 0.829187 \\ \text { Sum } & 4.310000 & 8.210000 & 1.380000 & 133.0400 & 111.3400 \\ \text { Sum Sq. Dev. } & 1.201492 & 0.357292 & 0.002500 & 8.629067 & 13.55677 \\ \text { Observations } & 12 & 12 & 12 & 12 & 12\end{array}$

Source: E-Views 9.0 Descriptive Output, 2021

\section{Interpretation}

Table 1 presents the descriptive statistics for the different variables of the study with an observation of 132 (i.e 11 firms x 12 years). Mean is the most commonly used measure of central tendency. The standard deviation shows the deviation/dispersion/variation from the mean. It is a measure of risk. The higher the standard deviation, the higher the risk. The standard deviation is a measure that summarizes the amount by which every value within a dataset varies from the mean. It is the most robust and widely used measure of dispersion. Skewness indicates the symmetry of the distribution. A skewed distribution which is positive indicates scores that are clustered to the left, and the tail of the distribution extending to the right while a negatively skewed distribution demonstrates scores that are clustered to the right and the tail of the distribution extends to the left. Kurtosis on the other hand, defines the peak of the distribution. Positive kurtosis is indicated by a peak. Negative kurtosis is indicated by a 
flat distribution. The data set in table 4.1 shows a mean and standard deviation for: $\mathrm{TQ}=$ 0.359 and 0.330; $\mathrm{EHSC}=0.147$ and 0.080; $\mathrm{WMC}=1.556$ and $0.097 ; \mathrm{CDC}=0.198$ and $0.157 ; \mathrm{ERC}=0.684$ and $0.180 ; \mathrm{CC}=0.115$ and $0.015 ; \mathrm{FSZ}=11.087$ and $0.886 ; \mathrm{LEV}=$ 9.278 and 1.110 suggesting a skewed distribution. Concerning the normality tests; skewness and kurtosis of the models were analyzed. All the variables in table 4.1 seem to indicate that the model seems to be close to the normal distribution since the results are positively skewed.

\section{Test of Hypothesis One}

Ho: Environmental Remediation Cost has no significant effect on Tobin's Q of Oil and Gas Companies listed on Nigeria Stock Exchange.

$\mathbf{H}_{\mathbf{I}}$ : Environmental Remediation Cost has significant effect on Tobin's Q of Oil and Gas Companies listed on Nigeria Stock Exchange.

\section{Table 2: Panel Least Square Regression Analysis between Environmental Remediation Cost and Tobin's $Q$ of listed Oil and Gas Companies}

Dependent Variable: TQ

Method: Least Squares

Date: 03/25/21 Time: 11:18

Sample: 20082019

Included observations: 12

\begin{tabular}{lrlrl}
\hline \hline \multicolumn{1}{c}{ Variable } & Coefficient & \multicolumn{1}{c}{ Std. Error } & t-Statistic & Prob. \\
\hline \hline \multicolumn{1}{c}{ C } & 0.405255 & 0.725111 & 5.558888 & 0.0000 \\
ERC & 0.014913 & 0.261830 & 8.056956 & 0.0000 \\
FSZ & 0.072754 & 0.169513 & 6.429193 & 0.0000 \\
LEV & -0.074918 & 0.161549 & -0.463750 & 0.6437 \\
\hline \hline R-squared & 0.711911 & Mean dependent var & 0.493763 \\
Adjusted R-squared & 0.623681 & S.D. dependent var & 0.845262 \\
S.E. of regression & 0.855212 & Akaike info criterion & 2.557563 \\
Sum squared resid & 85.57227 & Schwarz criterion & 2.649986 \\
Log likelihood & -150.7326 & Hannan-Quinn criter. & 2.595100 \\
F-statistic & 24.74661 & Durbin-Watson stat & 0.985170 \\
Prob(F-statistic) & 0.000000 & & \\
\hline \hline
\end{tabular}

E-Views 9.0 Regression Output, 2021

\section{Interpretation of Regression Result}

Table 2 shows the empirical effect of Environmental Remediation Cost on Tobin's Q of oil and gas companies in Nigeria. The Beta Coefficient value for the variables reveal that: ERC $\left(\beta_{1}\right)=0.014913 ;$ FSZ $\left(\beta_{2}\right)=0.072754$; LEV $\left(\beta_{3}\right)=-0.074918$. The slope coefficient; $\mathrm{P}\left(\mathrm{x}_{\mathrm{i}}=0.0000 ; \mathrm{x}_{2}=0.0000 ; \mathrm{x}_{3}=0.6437\right)$. Using the $\mathrm{T}$ - Ratio to test for their statistical significance, it was found that ERC and FSZ variables are statistically significant at 5\% level. This is due to the fact that their observed T-values are positive and above the "rule of thumb of 2". The other variable (LEV) is statistically non-significant because the observed t-value is either negative or far less than the 'rule of thumb' of 2 . However, the empirical results show that ERC, FSZ, LEV accounts for $62.4 \%$ of the changes in Tobin's Q while $37.6 \%$ are attributed to other factors apart from ERC, FSZ, LEV. The F-statistic $=24.74661$ with its 
associated Prob(F-statistic) $=0.000000$ implies that the overall joint effect of ERC, FSZ, and LEV on Tobin's Q is statistically significant at 5\% level.

The estimated relationship equation of the model is:

$\mathrm{TQ}=0.405255+0.014913 \mathrm{ERC}+\mu$

The implication is that, for there to be a unit/one naira increase in TQ there will be 0.014913 increase in ERC, holding other factors constant.

\section{Decision}

Going by the rule of thumb, $\mathrm{H}_{1}$ is accepted while Ho is rejected, since the P-value of the equation is 0.000000 which is less than the critical value of $0.05(5 \%)$. This implies that Environmental Remediation Cost has a significant positive effect on Tobin's Q at 5\% level of significance.

\section{Test of Hypothesis Two}

Ho: Compliance Cost has no significant effect on Tobin's Q of Oil and Gas Companies listed on Nigeria Stock Exchange.

$\mathbf{H}_{\mathrm{I}}$ : Compliance Cost has significant effect on Tobin's Q of Oil and Gas Companies listed on Nigeria Stock Exchange.

Table 3: Panel Least Square Regression Analysis between Compliance Cost and Tobin's $Q$ of listed Oil and Gas Companies

Dependent Variable: TQ

Method: Least Squares

Date: 03/25/21 Time: 11:19

Sample: 20082019

Included observations: 12

\begin{tabular}{lrlrr}
\hline \hline \multicolumn{1}{c}{ Variable } & Coefficient & \multicolumn{1}{c}{ Std. Error } & t-Statistic & Prob. \\
\hline \hline C & 0.737904 & 0.770739 & 5.957399 & 0.0000 \\
CC & -0.566456 & 0.469337 & -6.206928 & 0.0000 \\
FSZ & 0.056869 & 0.168724 & 0.337055 & 0.7367 \\
LEV & -0.081196 & 0.160200 & -2.506838 & 0.0096 \\
\hline \hline R-squared & 0.484157 & Mean dependent var & 0.493763 \\
Adjusted R-squared & 0.441121 & S.D. dependent var & 0.845262 \\
S.E. of regression & 0.849949 & Akaike info criterion & 2.545218 \\
Sum squared resid & 84.52232 & Schwarz criterion & 2.637641 \\
Log likelihood & -149.9857 & Hannan-Quinn criter. & 2.582754 \\
F-statistic & 9.560052 & Durbin-Watson stat & 1.001221 \\
Prob(F-statistic) & 0.000007 & & \\
\hline \hline
\end{tabular}

E-Views 9.0 Regression Output, 2021

\section{Interpretation of Regression Result}

Table 3 shows the empirical effect of Compliance Cost on Tobin's Q of oil and gas companies in Nigeria. The Beta Coefficient value for the variables reveal that: $\mathrm{CC}\left(\beta_{1}\right)=-$ 
0.566456; FSZ $\left(\beta_{2}\right)=0.056869 ;$ LEV $\left(\beta_{3}\right)=-0.081196$. The slope coefficient; $\mathrm{P}\left(\mathrm{x}_{\mathrm{i}}=0.0000\right.$; $\left.\mathrm{x}_{2}=0.7367 ; \mathrm{x}_{3}=0.0096\right)$. Using the $\mathrm{T}$ - Ratio to test for their statistical significance, it was found that $\mathrm{CC}$ and LEV are statistically significant at 5\% level, considering the fact that their observed T- values are above the "rule of thumb of 2", however, negative, while FSZ is statistically non-significant because the observed t-value is less than the 'rule of thumb' of 2 . However, the empirical results show that CC, FSZ, LEV accounts for $44.1 \%$ of the changes in Tobin's Q while 55.9\% are attributed to other factors apart from CC, FSZ, LEV, that could equally affect Tobin's Q. The F-statistic $=9.560052$ with its associated Prob(Fstatistic) $=0.000007$ implies that the overall joint effect of CC, FSZ, and LEV on Tobin's Q is statistically significant at $5 \%$ level.

The estimated relationship equation of the model is:

$\mathrm{TQ}=0.737904-0.566456 \mathrm{CC}+\mu$

The implication is that, for there to be a unit/one naira increase in TQ there will be 0.566456 decrease in $\mathrm{CC}$, holding other factors constant.

\section{Decision}

Going by the rule of thumb, $\mathrm{H}_{1}$ is accepted while Ho is rejected, since the P-value of the equation is 0.000007 which is less than the critical value of $0.05(5 \%)$. This implies that Compliance Cost has a significant negative effect on Tobin's Q of oil and gas companies at $5 \%$ level of significance.

\section{Discussion of Findings}

This study ascertained the affect of environmental cost on financial performance of listed oil and gas firms in Nigeria during the period 2008-2019.

It was found in hypothesis one that CC and LEV are statistically significant at 5\% level, considering the fact that their observed T- values are above the "rule of thumb of 2", however, negative, while FSZ is statistically non-significant because the observed t-value is less than the 'rule of thumb' of 2. However, the empirical results show that CC, FSZ, LEV accounts for $44.1 \%$ of the changes in Tobin's Q while $55.9 \%$ are attributed to other factors apart from CC, FSZ, LEV, that could equally affect Tobin's Q. The F-statistic $=9.560052$ with its associated Prob(F-statistic) $=0.000007$ implies that the overall joint effect of CC, FSZ, and LEV on Tobin's Q is statistically significant at 5\% level.

\section{Conclusion and Recommendations}

Premised on the colossal evidence from the analysis, this work concluded that active participation of oil and gas companies in Nigeria on environmental activities would significantly improve the financial performance of the oil and gas companies in Nigeria. Consequently, this work supports the growing evidence that environmental costs have a significant relationship and exerts significant effect on financial performance at $5 \%$ significant level. The study further concludes that the components of environmental costs considered in this study are important variables in explaining financial performance of listed oil and gas firms in Nigeria.

\section{Recommendations}


The following recommendations were made in line with the findings and conclusion of this study:

i. Since Environmental Remediation Cost and financial performance are positively related, then oil and gas firms should be environmentally friendly to enable them gain competitive advantage, high liquidity and reduced environmental cost in the long run.

ii. Corporate organizations should ensure that they comply with the environmental laws of the nation for improved and sustainable performance. 


\section{REFERENCES}

Amahalu, N.N., Okoye, P.V., \& Obi, J.C. (2018). Effect of sustainability reporting on economic value added of quoted brewery firms in Nigeria. Journal of Accounting, 7(1), 1-20.

Azomahou, T., Van, P.N., \& Wagner, M. (2017). Determinants of environmental and economic performance of firms: An empirical analysis of the European paper industry, International Summer School on .Economics, Innovation, Technological Progress, and Environmental Policy., Seeon (Bavaria), 8-12 September 2011, 1-70.

Bai, X., Pingli, L., \& Zhuang, Z. (2014).The impact of multi-dimensional environmental performance on firm performance and risk. Southampton Business School, University of Southampton, Southampton, Hampshire, UK.

Bartolacci, F., Paolini, A., Soverchia, M., \& Zigiotti, E. (2016). Waste management and financial performance: Evidence from Italian companies. Management International Conference, Pula-Croatia, 1-4 June, 2016.

Bartolomeo M., Bennett M., Bouma J.J., Heydkamp P., James P., \& Wolters T. (2012). Environmental management in Europe: Current practice and further potential, European Accounting Review, 9(1), 31-52.

Bessong, P.K., \& Tapang, A.T. (2012). Social responsibility cost and its influence on the profitability of Nigerian banks. International Journal of Financial Research, 3(4), 3345.

Bond, S.R., \& Cummins, J.G. (2004). Uncertainty and investment: An empirical investigation using data on analysts' profits forecasts. FEDS Working Paper, 2004-20.

Burnett, R.D., \& Hansen, D.R. (2017). Ecoefficiency: Defining a role for environmental cost management. Accounting, Organizations and Society, 33(6), 551-581.

Caputo, F., Veltri, S., \& Venturelli, A. (2017). Sustainability strategy and management control systems in family firms. Evidence from a case study. Sustainability, 9(6), 977.

Delmas, M.A., Nairn-Birch, N., \& Lim, J. (2015). Dynamics of environmental and financial performance: The case of greenhouse gas emissions. Organization \& Environment, 28(4) $374-393$.

Dobre, E., Stanila, G.O., \& Brad, L. (2015). The influence of environmental and social performance on financial performance: Evidence from Romania's listed entities. Sustainability, 7, 2513-2553.

Elias, A., Kostas, K., \& Dimitris, T. (2016). Environmental and financial performance. Is there a win-win or a win-loss situation? Evidence from the Greek manufacturing companies. Department of Economics, University of Patras, Greece, 1-28.

Eltaib, E. E. (2012). Environmental accounting Disclosures of Australian Oil and gas companies. Unpublished master's thesis: University of Wollongong.

Ezejiofor, R.A., John-Akamelu, R.C., Chigbo, B.E. (2016). Effect of sustainability environmental cost accounting on financial performance of Nigerian corporate organizations. International Journal of scientific research and management (IJSRM) 4(08), 4536-4549.

Falope, F. J., Offor, N. T. \& Ofurum, D. I. (2019). Environmental cost disclosure and corporate performance of quoted construction firms in Nigeria. International Journal of Advanced Academic Research Social and Management Sciences. 5(8) ISSN: 24889849.

Friedman, M. (1970). The social responsibility of business is to increase its profits. The New York Times Magazine, 13, 32-33. 
Goldenberg, (2009). Copenhagen climate change talk must fail, says top scientist. Available at: http://www.guardian.co.uk/environment/2009/dec/02/copenhagen-climate-jameshansen [Accessed December 05 2009].

Hayes, A. (2019). Q ratio - Tobin's q. https://www.investopedia.com/terms/q/qratio.asp. Retrieved 23/05/2019.

Hossain, M., Islam, K., \& Andrew, J. (2016). Corporate social and environmental disclosure in developing countries: Evidence from Bangladesh. Asian Pacific Conference. University of Wollongong.

Iheduru, N. G. \& Chukwuma, I. R. (2019).Effect of environmental and social cost on performance of manufacturing companies in Nigeria. International Journal of Accounting \& Finance Review. 4(2).

Jacob, M. (2011). Hope at last at the Durban conference on climate change. The Guardian. Available at: http://www.guardian.co.uk/commentisfree/2011/dec/11/durbanconference-climate-change. [Accessed 15 January 2012].

KPMG, United Nations Environment Programme (UNEP) (2006). Carrots and sticks for starters'. Current trends and approaches in voluntary and mandatory standards for sustainability reporting. Parktown: KPMG.

KPMG. (2012). Sustainability reporting-What you should know. KPMG.

Makori, D., \& Jagongo, A. (2013). Environmental accounting and firm profitability: An empirical analysis of selected firms listed in Bombay Stock Exchange, India. International Journal of Humanities and Social Science, 3(18), 273-285.

Maverick,

J.B.

(2018).

Financial

risk https://www.investopedia.com/terms/f/financialrisk.asp\#ixzz5FYQ2VIjj Follow us: Investopedia on Facebook

Okafor, T.G. (2018).Environmental costs accounting and reporting on firm financial performance: A survey of quoted Nigerian oil companies. International Journal of Finance and Accounting, 7(1), 1-6.

Okoye, P.V.C., Oraka, A. \& Ezejiofor, R. (2013). The effects of sustainability reporting on the growth of corporate organizations in Nigeria. European Journal of Economics, Finance and Administrative Sciences 1(8), 685-693.

Okoye P.V.C. \& Ezejiofor, R. A. (2013). An appraisal of sustainability environmental accounting in enhancing corporate productivity and economic performance. ISSN NO 2320-5407 International Journal of Advanced Research 1(8), 685-693. Journal homepage: http://www.journalijar.com

Oliff, M. D., \& Vandermerwe, S. (2017). Customers drive corporations green. Long Range Planning, 23 (6), 10-17.

Pariag-Maraye, N., Ansaram, K., \& Ramkalawon, N.D. (2017). Environmental management systems and financial performance: The case of listed companies in Mauritius. Scientific Research, 7(7), 1-14.

Peavler, R. (2017). Market to book financial ratio. https://www.thebalance.com/what-is-themarket-to-book-financial-ratio-393212. retrieved 13/3/2017

Rodriguez, F.J., \& Cruz, Y.M. (2007), Relationship between social-environmental responsibility and performance in hotel firms. Hospitality Management, 26, 824-839.

Rokhmawati, A., Sathye, M., \& Sathye. S. (2015). The effect of GHG emission, environmental performance, and social performance on financial performance of listed manufacturing firms in Indonesia. Procedia - Social and Behavioral Sciences $211(2015) 461-470$. 
Singh, R. K., Murty, H. R., Gupta, S. K., \& Dikshit, A. K. (2007). Development of composite sustainability performance index for steel industry. Ecological Indicators, 7, 565-588.

Solomon, J. F., \& Darby, L. (2005). Is private social, ethical and environmental reporting mythicizing or demythologizing reality? Accounting Forum, 29, 27-47.

Steven, B. (2019). Compliance, cost. https://www.accountingtools.com/articles/2017/9/21/compliance-cost. retrieved on $5 / 4 / 2019$.

Swinkels, E. (2012). The effect of publishing a GRI sustainability report on financial performance. Thesis submitted to Tilburg University, 1-45.

Tze, S.O., Boon, H.T., \&Yee, W.A. (2014).The impact of environmental improvements on the financial performance of leading companies listed in Bursa Malaysia. International Journal of Trade, Economics and Finance, 5(5), 386-391.

Udeh, \& Ezejiofor, R. .A. (2018). Effect of sustainability cost accounting on financial performance of telecommunication firms in Nigeria. Journal for Studies in Management and Planning. 4(6); ISSN: 2395-0463 Available at http://edupediapublications.org/journals/index.php/JSMaP/

Will, K. (2018). Compliance cost. https://www.investopedia.com/terms/c/compliancecost.asp. retrieved on 5/4/2019.

Worae, T.A., \& Ngwakwe, C.C. (2017). Environmental responsibility and financial performance nexus in South Africa: Panel granger causality analysis, Environmental Economics, 8(3), 29-34.

Worthington, B. (2009). What do the US and China's emission target actually mean? Available at http://www.guardian.co.uk/environment/cif-green/2009/nov/26/us-chinatarget-mean [Accessed December 4th 2009].

Zeng, S.X., Xu, X.D., Yin, H.T., \& Tam, C.M. (2012). Factors that drive Chinese listed companies in voluntary disclosure of environmental information. Journal of Business Ethics, 109(3), 309-321. 